\title{
The effect of precooling on short term performance
}

\author{
Panagiotis Gkrilias ${ }^{1,2 *}$, Athanasios Zavvos', Niki Manolaki, Nikolaos Geladas', Maria Koskolou', \\ Spyros Athanasopoulos ${ }^{1}$
}

From 15th International Conference on Environmental Ergonomics (ICEE XV)

Portsmouth, UK. 28 June - 3 July 2015

\section{Introduction}

The benefits of precooling have been widely studied and are mainly attributed to a smaller rise of body core temperature (Tc) and improved cardiovascular responses in prolonged exercise [1], [2]. Regarding the performance of short-term high-intensity exercise, after precooling, the results are conflicting [3]. The purpose of this study was to examine whether short-term performance could be affected by whole body immersion (at chest level with arms and hands out of the water) for 30 minutes at $16{ }^{\circ} \mathrm{C}$ to $18{ }^{\circ} \mathrm{C}$.

\section{Methods}

On two occasions, 10 male volunteers age: 23.2 (2) yr, height: 178,1 (7.1) cm, body mass: $77.6(6.4) \mathrm{kg}$, body fat: $\left.12(2.7) \%, \mathrm{VO}_{2 \max }: 44.3(4.9) \mathrm{mL} \cdot \mathrm{Kg}^{-1} \cdot \mathrm{min}^{-1}\right\}$ performed an intermittent exercise bout (Cisp), consisting of five repeated 5-sec sprints on a mechanical cycle ergometer [4] and, subsequently, a short high-intensity shuttle-run test $(6 \times 5$ meters $)$ either or without precooling (Cool Vs Con) in random and counterbalanced order. The Cisp was performed in an environmental chamber (temperature: $31{ }^{\circ} \mathrm{C}$ to $33{ }^{\circ} \mathrm{C}$, rh $40 \%$ to $50 \%$ ) while, for technical reasons the shuttle-run test was performed in thermoneutral environment $\left(19{ }^{\circ} \mathrm{C}\right.$ to $\left.22^{\circ} \mathrm{C}\right)$. Performance was evaluated as the peak power output per sprint (Pmax) and the total time to complete the shuttle-run test. In specific parts of the protocol rectal temperature $\left(\mathrm{T}_{\mathrm{re}}\right)$, the temperature of the finger (Tfin) and forearm (Tfarm), heart rate ( $\mathrm{Hr})$, thermal sensation (Ts) and perceived fatigue (Borg scale) were recorded.

\footnotetext{
* Correspondence: gkriliasphysio@gmail.com ${ }^{1}$ Department of Sports Medicine and Biology of Exercise, Faculty of Physical Education and Sport Science, University of Athens, Greece Full list of author information is available at the end of the article
}

\section{Results}

A reduction $(\mathrm{p} \leq 0.001)$ in $P \max \left\{P \max 1^{\text {st }}\right.$ sprint (0-2 min): Cool: 806.7 (63.1) Watt Vs Con: 860.9 (78.7) Watt, Pmax $5^{\text {th }}$ sprint (8-10 min): Cool: 856.8 (74.7) Vs Con: $912.8(70.4)$ Watt $\}$ and a tendency $(\mathrm{p}=0.06)$ for longer time to complete the shuttle-run test were observed in Cool $\{10.43(0.66)$ sec $\}$ compared to Con $\{10.18(0.41) \mathrm{sec}\}$ condition. The $\mathrm{T}_{\mathrm{re}}$ during the Cisp test in Cool condition \{Tre 0-2 min Cool: 37,10 (0.72) ${ }^{\circ}$ C, Tre 8-10 min Cool: $\left.37,35(0.77){ }^{\circ} \mathrm{C}\right\}$, was lower $(\mathrm{p} \leq$ $0.05)$, compared with Con values $\{$ Tre $0-2$ min Con: $37.54(0.25){ }^{\circ} \mathrm{C}$, Tre $8-10 \mathrm{~min}$ Con: $\left.37.84(0.18){ }^{\circ} \mathrm{C}\right\}$. The vasoconstriction index (Tfarm-Tfin) [5], was higher ( $\mathrm{p} \leq$ 0.001) throughout the duration of the exercise protocol in Cool than in the Con condition Index 0-2 min: Cool: $5.56(0.76){ }^{\circ} \mathrm{C}$ Vs Con: $0.66(2.15){ }^{\circ} \mathrm{C}$, Index 8-10 min: Cool: 3.94 (2.09) ${ }^{\circ} \mathrm{C}$ Vs Con: $\left.-0.63(1.63){ }^{\circ} \mathrm{C}\right\}$.

\section{Discussion}

After precooling with whole body immersion a reduction in short term performance was observed which was probably due to neuromuscular system dysfunction caused by coolness.

\section{Conclusion}

This type of information, about the short term performance reduction after precooling, observed in our study, should be taken into consideration by the technical and medical staff of athletic teams, in sports which demand explosiveness and somatic contact right after precooling.

\section{Authors' details}

${ }^{1}$ Department of Sports Medicine and Biology of Exercise, Faculty of Physical Education and Sport Science, University of Athens, Greece. ${ }^{2}$ Technological Educational Institute (TEI) of Western Greece, Department of Physical Therapy, Aigio Achaias, Greece. 


\section{References}

1. Marino FE: Methods, advantages, and limitations of body cooling for exercise performance. Br J Sports Med 2002, 36:89-94.

2. Quod M, Martin D, Laursen P: Cooling athletes before competition in the heat. Sports Med 2006, 36(8):671-682.

3. Bleakley CM, Costello JT, Glasgow PD: Should athletes return to sport after applying ice? A systematic review of the effect of local cooling on functional performance. Sports Medicine 2012, 42(1):69-87.

4. Castle P, Macdonald L, Philp A, et al: Precooling leg muscles improves intermittent sprint exercise performance in hot, humid conditions. J Appl Physiol 2006, 100:1377-1384.

5. Rubinstein HE, Sessler DI: Skin surface temperature gradients correlate with fingertip blood flow in humans. Anesthesia 1990, 73:541-545.

doi:10.1186/2046-7648-4-S1-A124

Cite this article as: Gkrilias et al:: The effect of precooling on short term performance. Extreme Physiology \& Medicine 2015 4(Suppl 1):A124.

\section{Submit your next manuscript to BioMed Central} and take full advantage of:

- Convenient online submission

- Thorough peer review

- No space constraints or color figure charges

- Immediate publication on acceptance

- Inclusion in PubMed, CAS, Scopus and Google Scholar

- Research which is freely available for redistribution

Submit your manuscript at www.biomedcentral.com/submit 